\title{
Population dynamics of the brine shrimp Artemia persimilis Piccinelli \& Prosdocimi, 1968 (Crustacea, Anostraca) in a hypersaline lake of the Central Pampa (Argentina)
}

\author{
Alicia M. Vignatti ${ }^{1 *}$, Gabriela C. Cabrera ${ }^{1}$ \& Santiago A. Echaniz ${ }^{1}$ \\ ${ }^{1}$ Facultad de Ciencias Exactas y Naturales, Universidad Nacional de La Pampa. Avenida Uruguay 151. 6300. \\ Santa Rosa, La Pampa, Argentina \\ *Corresponding author: Alicia M. Vignatti,e-mail: aliciavignatti@cpenet.com.ar; \\ aliciavignatti@exactas.unlpam.edu.ar
}

VIGNATTI, A. M., CABRERA, G. C., ECHANIZ, S. A. Population dynamics of the brine shrimp Artemia persimilis Piccinelli \& Prosdocimi, 1968 (Crustacea, Anostraca) in a hypersaline lake of the Central Pampa (Argentina). Biota Neotropica. 17(3): e20170353. http://dx.doi.org/10.1590/1676-0611-BN-2017-0353

\begin{abstract}
The anostracan Artemia is one of the few organisms that can inhabit hypersaline lakes. In Argentina, this genus is represented by two species: the invasive A. franciscana Kellogg, 1906 and the autochthonous $A$. persimilis Piccinelli \& Prosdocimi, 1968, the latter being the only one recorded in the province of La Pampa. Some of the biological aspects of $A$. persimilis are known based on laboratory studies, and data on its ecology in natural conditions are scarce. The aim of this work is to present information on the density, biomass, and population structure of A. persimilis in relation to environmental variables in Utracán, a hypersaline lake of the semiarid Central Pampa of Argentina. Water and zooplankton samples were taken monthly from May 2009 until August 2010. The mean density and biomass were 56.98 ind. $\mathrm{L}^{-1}( \pm 106.64)$ and $1.23 \mathrm{mg} . \mathrm{L}^{-1}( \pm 1.35)$, respectively. The species was negatively affected by salinity, and it was absent between November and February, when salinity exceeded 320 g.L. $\mathrm{L}^{-1}$. However, when it was present, even during the months of higher salinity, a high proportion of naupliar stages was found, which could indicate that, in nature, A. persimilis can reproduce with high salinity. Although it has been indicated that $A$. persimilis could be displaced by $A$. franciscana, the highest tolerance of the former at low temperatures, which allowed the population to continue reproducing at values close to $3^{\circ} \mathrm{C}$, would limit its displacement. However, an increase in the temperature of lakes as a result of global warming could modify this situation and allow the advance of the introduced species to the south.
\end{abstract}

Keywords: Artemia persimilis, hypersaline lakes, Pampa Argentina

\section{Dinámica poblacional de Artemia persimilis Piccinelli \& Prosdocimi, 1968 (Crustacea, Anostraca) en un lago hipersalino de la Pampa Central (Argentina)}

Resumen: Los anostracos del género Artemia son algunos de los pocos organismos que pueden habitar los lagos hipersalinos. En Argentina, este género está representado por dos especies: la introducida A. franciscana Kellogg, 1906 y la autóctona $A$. persimilis Piccinelli \& Prosdocimi, 1968, esta última, la única especie registrada en la provincia de La Pampa. Algunos aspectos de la biología de A. persimilis basados en estudios de laboratorio son conocidos, pero la información sobre su ecología en condiciones naturales es muy escasa. El objetivo de este trabajo es presentar información sobre la densidad, biomasa y la estructura de la población de $A$. persimilis en relación con parámetros ambientales en Utracán, un lago hipersalino de la Pampa Central semiárida de Argentina. Se tomaron muestras mensuales de zooplancton y agua desde mayo de 2009 hasta agosto de 2010. La densidad y biomasa medias a lo largo del estudio fueron 56.98 ind.L $\mathrm{L}^{-1}( \pm 106.64)$ y $1.23 \mathrm{mg} . \mathrm{L}^{-1}( \pm 1.35)$. La especie fue afectada negativamente por la salinidad, dado que no se registró entre noviembre y febrero, cuando la misma excedió los 320 g. $\mathrm{L}^{-1}$. Sin embargo, cuando estuvo presente, aún en los meses de mayor salinidad se encontró una proporción de estadios naupliares elevada, lo que podría indicar que, en la naturaleza, $A$. persimilis puede reproducirse con alta salinidad. A pesar de que se ha indicado que $A$. persimilis podría ser desplazada por $A$. franciscana, la mayor tolerancia de la primera a bajas temperaturas, que permitió que a valores cercanos a $3^{\circ} \mathrm{C}$ la población continuara reproduciéndose, limitaría su desplazamiento. Sin embargo, un aumento de la temperatura de los lagos como consecuencia del calentamiento global podría modificar esta situación y permitir el avance de la especie introducida hacia el sur.

Palabras-clave: Artemia persimilis, lagos hipersalinos, Pampa Argentina 


\section{Introduction}

The anostracan Artemia is one of the few organisms that can inhabit hypersaline lakes (total dissolved solids $>50$ g.. $\mathrm{L}^{-1}$ ) because it has physiological mechanisms to withstand osmotic stress (Gajardo \& Beardmore 2012). In Argentina, the genus Artemia is represented by two species: Artemia franciscana Kellogg, 1906 and Artemia persimilis Piccinelli \& Prosdocimi, 1968 (Cohen 2012). The former is a species of North America that would have been introduced to South America by the migrations of birds (Muñoz et al. 2013), and its distribution is limited to the latitude of $33^{\circ} \mathrm{S}$ (Ruiz et al. 2008). A. persimilis is autochthonous, restricted to environments in Chile and Argentina (Clegg \& Gajardo 2009), and at present is the only species recorded in the province of La Pampa (Vignatti et al. 2014, Echaniz et al. 2015).

The species of this genus have economic importance, since from the naupliar stage until adulthood they are used as live food in the breeding of several fish and crustaceans of commercial value, because they constitute a source of proteins, lipids, essential amino acids, and unsaturated fatty acids beneficial to the organisms in culture (Dhont \& Lavens 1996, Dhont \& Sorgeloos 2002). This has caused some biological aspects of $A$. persimilis to be studied in the laboratory (Pastorino et al. 2002, Mechaly et al. 2004, 2013, Sato et al. 2004, Medina et al. 2007), but there is little information about its geographical distribution and its ecology under natural conditions. In addition, increasing knowledge about the biology of the species is an important aspect, as its geographical distribution could be in decline, because it has been proven that $A$. franciscana tends to displace native species of the places it colonizes (Green et al. 2005) due to its higher phenotypic plasticity (Browne \& Wanigasekera 2000, Clegg \& Gajardo 2009, Vikas et al. 2012).

In the central semi-arid region of Argentina, the presence of $A$. persimilis was registered in some hypersaline lakes. In Guatraché, located to the southeast of the province of La Pampa, the species was found at a time when the concentration of dissolved solids was higher than $400 \mathrm{~g} . \mathrm{L}^{-1}$, the highest salinity reported for this species in the literature (Vignatti et al. 2014). The population dynamics of $A$. persimilis have been described in La Amarga, but it is a lake with unique characteristics, because it belongs to a river system that is inactive due to strong anthropogenic influence (Echaniz et al. 2015).

Given the scarcity of information on the population dynamics of the species under natural conditions and the influence of environmental factors, the objectives of this work were to know the main limnological parameters, density, biomass, and population structure of $A$. persimilis and to establish relationships between the biotic and environmental variables in Utracán, a typical hypersaline lake in the Central Pampa of Argentina.

\section{Materials and methods}

\section{Study area}

Utracán $\left(37^{\circ} 16^{\prime} \mathrm{N}, 64^{\circ} 35^{\prime} \mathrm{W}\right)$ is a shallow lake located in the central region of the province of La Pampa (Figure 1) in a protected area of the municipality of the city of General Acha. It is located in a dune landscape, surrounded by natural vegetation, with grasslands and native forest (Figure 2).

Utracán Lake is fed principally by rainfall and groundwater inputs. It is in a region where the average annual rainfall is around $600 \mathrm{~mm}$ (Casagrande et al. 2006), with peaks in summer and early autumn (Vergara \& Casagrande, 2012). However, the rains during 2009 and 2010 only reached 312 and $499 \mathrm{~mm}$ respectively (http://www.policia.lapampa.gov. ar/contenidos/ver/lluvias). Since the lake is located in an arheic basin, water outlets are usually produced by evaporation.

Fish have never been recorded in Utracán, probably due to the high salinity and lack of connection to other aquatic ecosystems. In its basin only livestock farming is done. During the period included in this work, only scarce flamingoes (Phoenicopterus chilensis Molina, 1782) were spotted sporadically in the lake's avifauna.

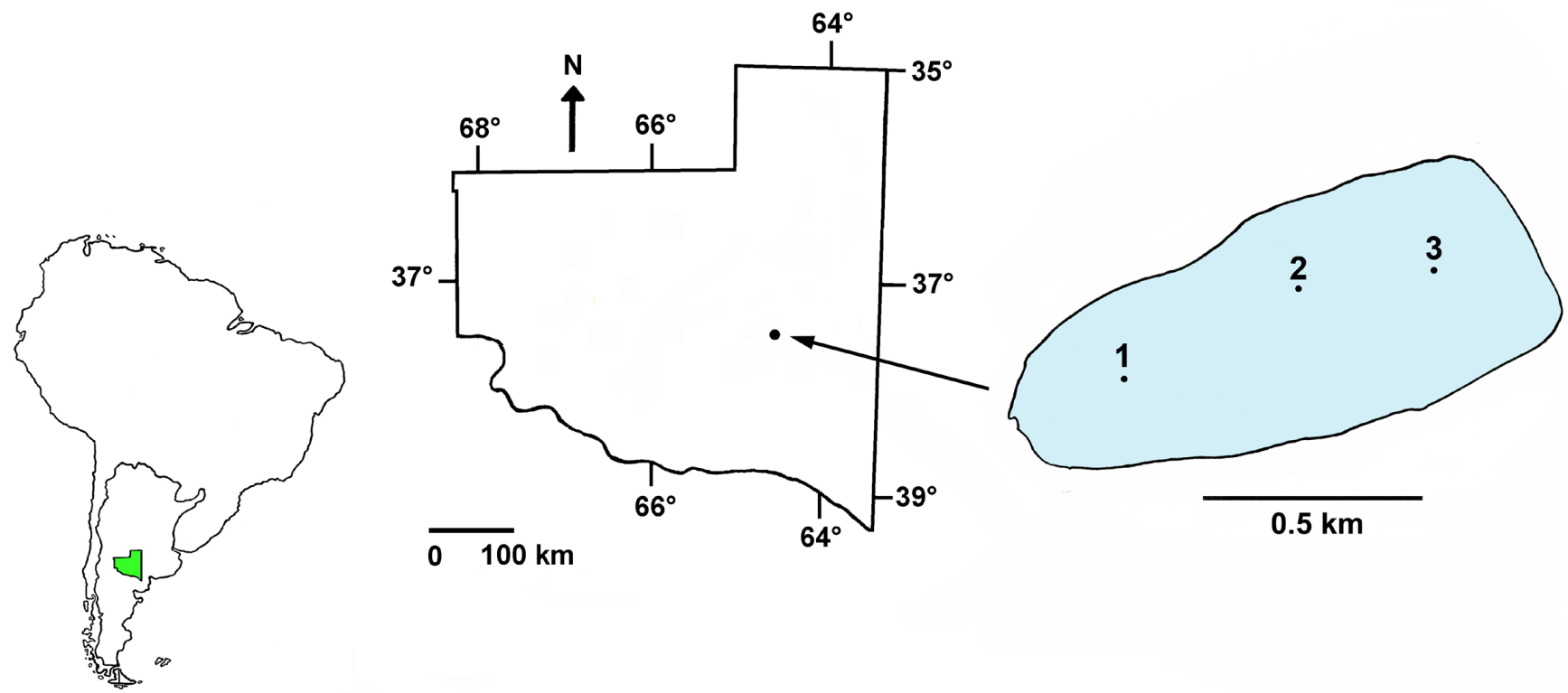

Figure 1. Geographic location of Utracán Lake. The light blue area is the extension of the lake in May 2009. 1, 2, and 3: sampling sites 


\section{Field and laboratory work}

Samples were collected monthly from May 2009 until August 2010. Between May and October 2009 the sampling was conducted in the three stations along the longest axis of the lake (Figure 1), totaling 18 samples. Subsequently, the station located in the west of the lake (Figure 1, point 1), disappeared when the water level decreased, which meant that only samples at sites 2 and 3 were taken (for a total of 22 samples).

Water temperature, dissolved oxygen concentration (oximeter Lutron $^{\circledR}$ OD 5510), water transparency (Secchi disc), and $\mathrm{pH}$ (digital pH meter Cornning ${ }^{\circledR}$ PS 15) were determined in each station.

Salinity was determined by means of the gravimetric method with drying at $104^{\circ} \mathrm{C}$. Chlorophyll $a$ concentration (Chl-a) was measured by extraction with aqueous acetone and spectrophotometry (Arar 1997, APHA 1992), the total phosphorus (TP) by the ascorbic acid method after digestion with acidic persulfate, and the Kjeldahl total nitrogen (TKN) by the digestion method with sulfuric acid and colorimetric determination with Nessler reagent (APHA 1992).

Quantitative zooplankton samples were collected in each site. Because of the shallow depth, these samples were taken with graduated containers that integrated the water column and were filtered through a $0.04 \mathrm{~mm}$ mesh-size net. A qualitative sample was also taken with a similar net. All the samples were anesthetized with $\mathrm{CO}_{2}$ to avoid contractions that may deform the individuals collected and were kept refrigerated until fixation with formaldehyde $4 \%$.

Counts to determine the density of zooplankton were made in Bogorov chambers under a stereomicroscope. The stages of $A$. persimilis were determined in Sedgwick Rafter chambers under a microscope at 40-100X following the criteria of Cohen et al. (1999). These authors grouped the development of this species into five periods. The first, or naupliar period, is characterized by the presence of a naupliar, polygonal and frontal eye, segmentation sketches in the post-mandibular region, and a thin middle indentation in the posterior region which, towards the end of the period, becomes a deep proctodeal invagination. The metanaupliar period is characterized by the presence of protuberances corresponding to compound eyes. On each side of the naupliar eye, thoracic segments delimited by furrows and protuberances correspond to the first pairs of phyllopods. The third period, the post-metanaupliar,

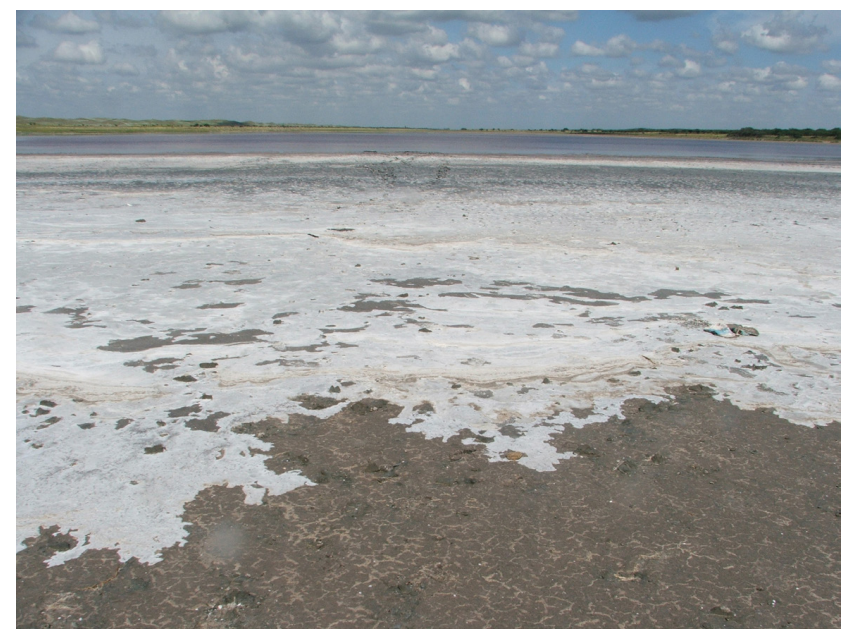

Figure 2. Utracán Lake in February 2010 is characterized by the development of the peduncle of the compound eyes, which become prominent and pigmented, and by the presence of seven to eleven thoracic segments, whose phyllopods are progressively acquiring setae and, as a result, their functions of locomotion and feeding. During this period the delimitation of the abdomen occurs. During the fourth or post-larval period, the antennae gradually reach the shape, size, and characteristics that distinguish males and females. In both sexes the genital region and related structures reach their full development and each furcal branch (uropod) carries two setae and a thorn or three setae. During the fifth and final adult period, the male penises reach the typical morphology of the species, with a mound with spines in the inner angle of its basal portion and spines in the eversible portion. The female's ovaries show oocytes and the ovisacs acquire the typical triangular form. The posterior end of the abdomen of both sexes carries a pair of furcal branches (uropods), each with three to five feathery silks.

The biomass was determined by drying to constant weight of all specimens (previously washed) of $5 \mathrm{~mL}$ subsamples, obtained with a Russell subsampler.

To examine relations between environmental factors and A. persimilis attributes, Spearman correlation coefficients were calculated (Sokal \& Rohlf 1995, Zar 1996) and principal components analysis (PCA) (Pérez López 2004) was performed. We used Infostat software (Di Rienzo et al. 2010).

All applicable international, national, and institutional guidelines for the care and use of animals were followed.

\section{Results}

\section{Environmental parameters}

The depth was always reduced. It was at maximum at the beginning of the study, and, after fluctuating markedly by evaporation and the influence of relatively small precipitations, the lake was dried in September 2010 (Figure 3). The mean salinity was higher than 230 g.L-1 (Table 1) and also varied widely and abruptly, from a maximum of $424.7 \mathrm{~g} . \mathrm{L}^{-1}$, registered in February 2010, to a minimum of 99.2 g.L. $\mathrm{L}^{-1}$, the following month (Figure 3). Significant negative correlation was found between both parameters $\left(r_{\mathrm{s}}=-0.91 ; \mathrm{p}<0.0001\right)$.

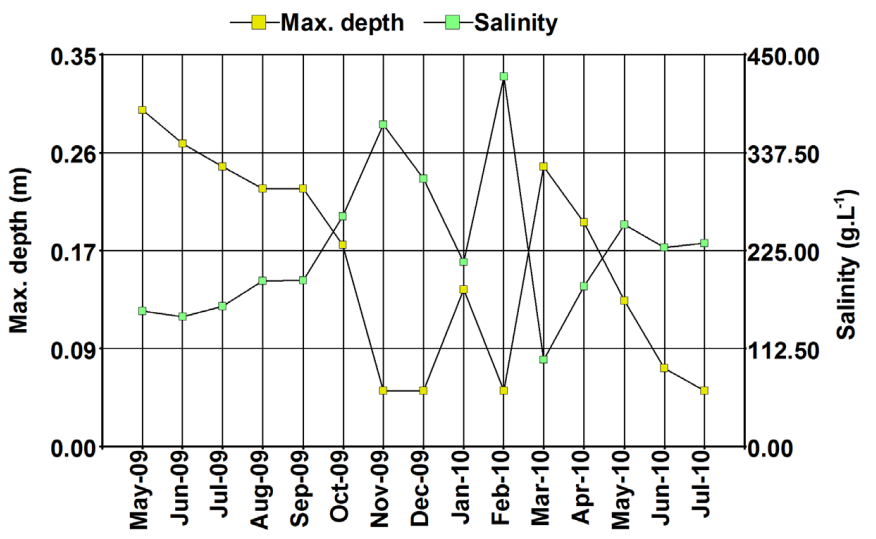

Figure 3. Monthly variation of the maximum depth and salinity in Utracán Lake between May 2009 and August 2010 
Table 1. Main limnological parameters, total density of Artemia persimilis, and stages (mean values \pm standard deviation) in saline lakes of La Pampa in which the species was recorded.

\begin{tabular}{lccc}
\hline & Utracán (2009-2010) & Guatraché (2011-2012)* & La Amarga (2007)** \\
\hline Water temperature $\left({ }^{\circ} \mathrm{C}\right)$ & $16.53 \pm 7.61$ & $23.78 \pm 10.87$ & $14.58 \pm 7.99$ \\
Salinity $\left(\mathrm{g} . \mathrm{L}^{-1}\right)$ & $238.05 \pm 92.34$ & $345.40 \pm 48.25$ & $115.51 \pm 19.02$ \\
$\mathrm{pH}$ & $9.21 \pm 0.09$ & $7.73 \pm 0.23$ & $7.82 \pm 0.53$ \\
Transparency $(\mathrm{m})$ & $0.11 \pm 0.06$ & $>0.2$ & $1.54 \pm 0.15$ \\
Chlorophyll- $a$ (mg. $\left.{ }^{-3}\right)$ & $39.16 \pm 22.69$ & $8.39 \pm 6.97$ & $1.65 \pm 1.16$ \\
Dissolved oxygen $\left(\mathrm{mg} . \mathrm{L}^{-1}\right)$ & $8.11 \pm 3.07$ & $\mathrm{~N} / \mathrm{D}$ & $6.83 \pm 1.23$ \\
Total density (ind. $\left.\mathrm{L}^{-1}\right)$ & $56.98 \pm 106.64$ & $9.60 \pm 16.12$ & $1.56 \pm 2.17$ \\
Nauplii density (ind. $\left.\mathrm{L}^{-1}\right)$ & $11.59 \pm 33.68$ & $2.15 \pm 1.12$ & $0.46 \pm 0.63$ \\
Metanauplii density (ind. $\left.\mathrm{L}^{-1}\right)$ & $16.10 \pm 38.54$ & $1.22 \pm 1.50$ & $0.82 \pm 1.35$ \\
Postmetanauplii density (ind. $\left.\mathrm{L}^{-1}\right)$ & $22.87 \pm 43.04$ & $5.77 \pm 11.80$ & $0.08 \pm 0.08$ \\
Postlarvae density (ind. $\left.\mathrm{L}^{-1}\right)$ & $3.78 \pm 6.48$ & $1.08 \pm 1.57$ & $0.14 \pm 0.16$ \\
Adults density (ind. $\left.\mathrm{L}^{-1}\right)$ & $2.73 \pm 3.95$ & $1.30 \pm 2.05$ & $0.05 \pm 0.06$ \\
\hline
\end{tabular}

*Vignatti et al. 2014;** Echaniz et al. 2015

The water temperature varied between a minimum of $3.43^{\circ} \mathrm{C}$ (July 2009) and a maximum of $31.2^{\circ} \mathrm{C}$ (February 2010) (Figure 4). The dissolved oxygen concentration ranged from values close to $1.5 \mathrm{mg} . \mathrm{L}^{-1}$ in November and February to a maximum of $12 \mathrm{mg} . \mathrm{L}^{-1}$ in April. Negative correlation was found between both parameters $\left(r_{s}=-0.72 ; p=0.0054\right)$.

Chl- $a$ mean concentration was close to $38 \mathrm{mg} \cdot \mathrm{m}^{-3}$ (Table 1) and was very variable, although it did not show a seasonal pattern. The concentration was less than $20 \mathrm{mg} \cdot \mathrm{m}^{-3}$ on three occasions but had a peak of $101.26 \mathrm{mg} \cdot \mathrm{m}^{-3}$ in January (Figure 4) and no significant correlation was found with salinity $\left(r_{s}=0.33 ; p=0.2189\right)$ and water temperature $\left(r_{s}=0.10 ; p=0.6984\right)$. The transparency of the water was always highly reduced and highly variable, since it fluctuated between $0.05 \mathrm{~m}$, registered on five occasions, and a maximum of $0.25 \mathrm{~m}$, recorded in March and no seasonal pattern was detected. A positive correlation was found between this variable and maximum depth of the lake $\left(\mathrm{r}_{\mathrm{s}}=0.93 ; \mathrm{p}<0.0001\right)$ but a negative one between water transparency and salinity $\left(\mathrm{r}_{\mathrm{s}}=-0.89 ; \mathrm{p}<0.0001\right)$. The correlation between water transparency and Chl- $a$ concentration was not significant $\left(r_{\mathrm{s}}=-0.40 ; \mathrm{p}=0.1352\right)$.

\section{Artemia persimilis biology}

The species was recorded over 11 months, from the beginning of the study until October 2009, when the salinity fluctuated between 155.5 and 264.5 g.L. ${ }^{-1}$, and between March and July 2010, when the

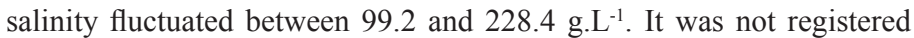
between November 2009 and February 2010, when the concentration of dissolved solids exceeded 320 g.L $\mathrm{L}^{-1}$, nor in August 2010, when salinity exceeded 380 g.L.- ${ }^{-1}$ just before the drying of the lake. The species' mean density and biomass throughout the study were 56.98 ind.L $\mathrm{L}^{-1}( \pm 106.64)$ and $1.23 \mathrm{mg} . \mathrm{L}^{-1}( \pm 1.35)$, respectively, and correlation was found between both parameters $\left(r_{s}=0.94 ; p=0.000\right)$. Since the two biological parameters were lower on the occasions when the concentration of dissolved solids was higher, a correlation was found between total population density and biomass and salinity $\left(r_{s}=-0.75 ; p=0.0008\right.$ and $\left.r_{s}=-0.67 ; p=0.0049\right)$, but not with other environmental parameters.

The PCA analysis, whose first two components explained $67.1 \%$ of the variance (Figure 5), also showed that the salinity was the environmental factor that has the greatest influence on the density and biomass of $A$. persimilis and also showed certain influence of this species on concentration of phytoplankton chlorophyll- $a$ and therefore, on the water transparency.

In both years, the density peaks were recorded during the autumn and were 180.75 ind. $\mathrm{L}^{-1}$ in June 2009 and 399.3 ind. $\mathrm{L}^{-1}$ in April 2010 (Figure 6), when the naupliar stages predominated in the population (Figure 7). However, during 2009 the maximum biomass was recorded during the winter, in

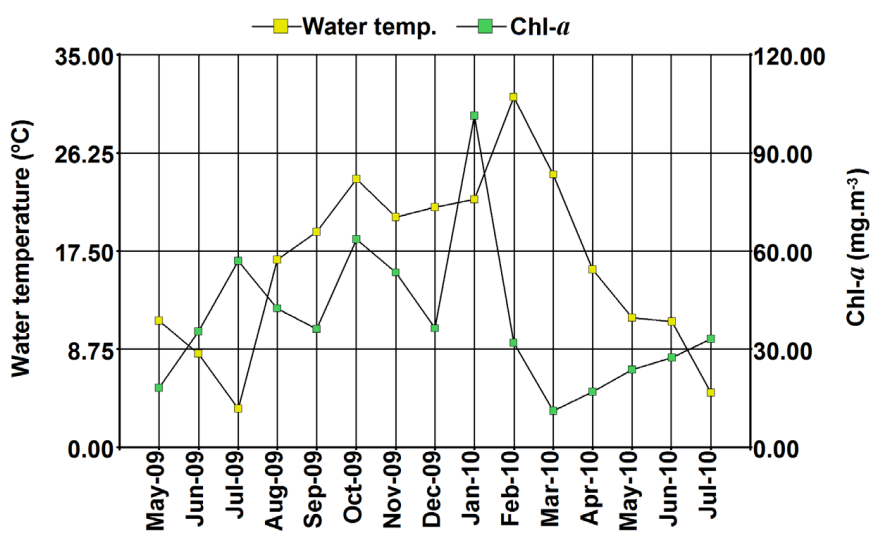

Figure 4. Monthly variation of the water temperature and phytoplankton chlorophyll- $a$ concentration in Utracán Lake between May 2009 and August 2010

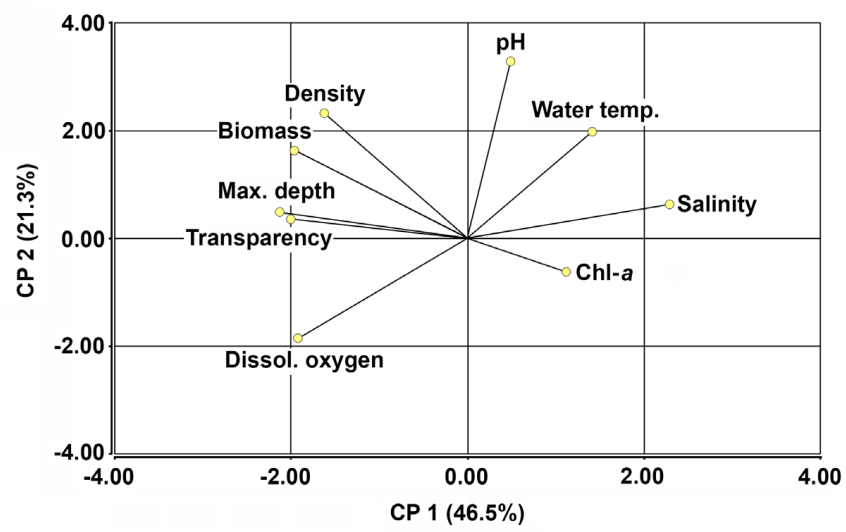

Figure 5. Biplot with results of Principal Component Analysis

August, when it reached $2.56 \mathrm{mg} . \mathrm{L}^{-1}$, when the adult specimens predominated in the population. In 2010 the biomass peak was higher, since it reached $4.88 \mathrm{mg} . \mathrm{L}^{-1}$ and coincided with that of density. The lowest densities were recorded in the months prior to the recordings of the maximum salinities, 16.33 ind. $\mathrm{L}^{-1}$ in October 2009 and only 0.83 ind. $\mathrm{L}^{-1}$ in July 2010, times at which the population was dominated by postlarvae and adults (Figure 7). 


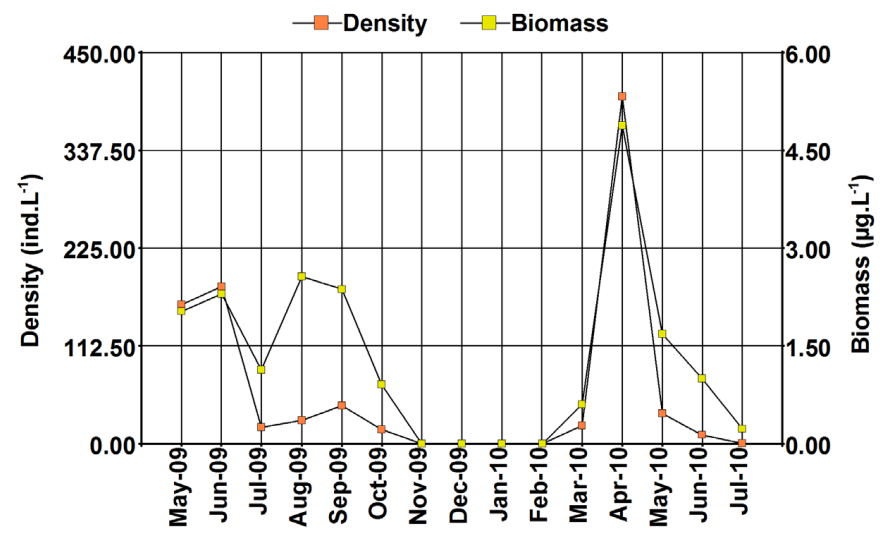

Figure 6. Variation of density and total biomass of Artemia persimilis in Utracán Lake during the study

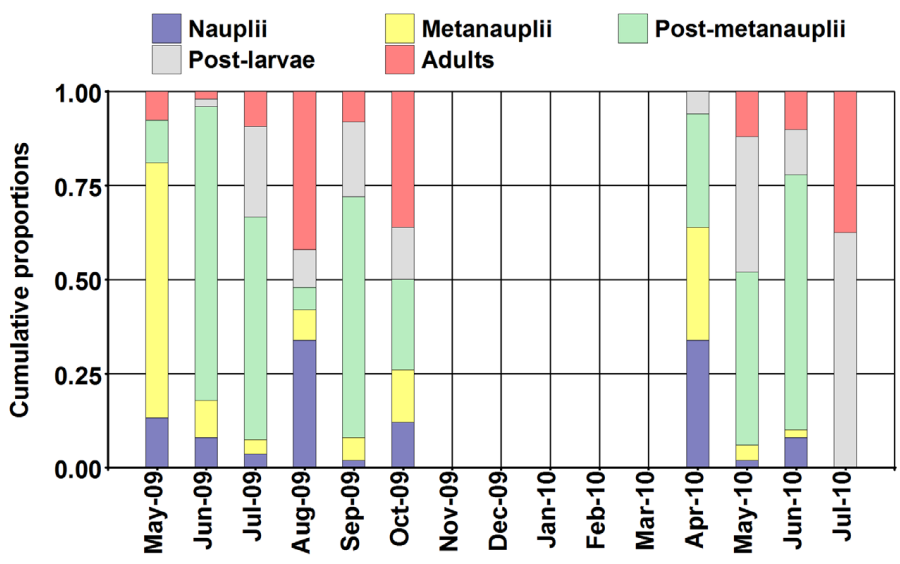

Figure 7. Proportions of the contribution of each stage to the total density of A. persimilis in Utracán Lake between May 2009 and July 2010

\section{Discussion}

Artemia persimilis was present for most of the sampling occasions; however, the negative effect of salinity was evident, since the species was absent between November and February, when the salinity was close to 370 g.L. ${ }^{-1}$.

Later recolonization may have been due to the hatching of cysts deposited in the egg bank of the sediments, since during all occasions a large number of dormant eggs were observed in the borders (Vignatti \& Echaniz, pers. observ.)

The situation in Utracán is different from that found in Guatraché, another pampean lake, where the species was recorded when the salinity was higher than 400 g.L $L^{-1}$, after which, due to an increase in the concentration of dissolved solids, it was not found (Vignatti et al. 2014). In La Amarga, the third hypersaline lake studied in La Pampa, A. persimilis was found at all times, probably because the maximum salinity remained within the tolerance range of the species (Echaniz et al. 2015).

In both Utracán and Guatraché populations (Vignatti et al. 2014), a relatively high proportion of naupliar stages was found in the months of higher salinity, although the population later disappeared from the water column. This could indicate that, in the wild, A. persimilis can reproduce up to these limits of salinity. On the other hand, in both lakes a relatively high proportion of larval stages were found during the colder months, which could indicate that the low temperatures would not affect reproduction.
Whereas in Guatraché and La Amarga the average density was reduced, in Utracán it was almost 6 and 35 times higher, respectively (Table 1). Considering that the concentrations of phytoplankton chlorophyll-a that were determined in the former two lakes were considerably lower than those of Utracán (Table 1), the greater density of the species in the latter could be due to the greater availability of food, given the greater quantities of phytoplankton present in this lake.

Although information on the geographic distribution of the Artemia genus in Argentina is scarce, in the few saline lakes in the north of the country where specimens were found, they corresponded to $A$. franciscana (Ruiz et al. 2008). The southernmost register corresponded to Las Tunas Lake in the province of Cordoba, where it could have come because of dispersal by birds (Muñoz et al. 2013). At present, all records to the south of $33^{\circ}$ latitude, both in the center of the country and in Patagonia, correspond to A. persimilis (Ruiz et al. 2008, Vignatti et al. 2014, Echaniz et al. 2015).

As previously mentioned, it is thought that $A$. franciscana could be in geographical range expansion due to its great colonizing ability (Clegg $\&$ Gajardo, 2009), which may displace the native species (Green et al. 2005). One possible limitation to A. franciscana's progress towards the south would be its lower tolerance to low temperatures (Amat et al. 2004, Vignatti et al. 2014), to the point that it was not recorded in the Great Salt Lake of Utah with temperatures below $3{ }^{\circ} \mathrm{C}$ (Wurtsbaugh \& Gliwicz 2001). In Argentina, where there are few studies that cover annual cycles in saline lakes of this species, there is only the record in winter (July) in Mar Chiquita Lake, when the water temperature was $10.7^{\circ} \mathrm{C}$ (Pilati et al. 2016).

In Utracán, located much to the south, $A$. persimilis was recorded in July, with a temperature only above $3^{\circ} \mathrm{C}$. Considering that a high proportion of juvenile stages were counted at that time, the species' reproduction may not be affected by the low temperature, which could constitute an effective defense against possible invasions of their congeneric species. However, considering that climate change is a particularly important phenomenon in Argentina's arid diagonal (D'Ambrosio et al. 2016), this situation could change drastically, since a small increase in the mean water temperature of the lakes would allow A. franciscana to colonize lakes located farther south than its present distribution, which could potentially lead to local extinctions of the native species. This necessitates new studies on both species in saline lakes located between $33^{\circ}$ and $37^{\circ} \mathrm{S}$, in what can be considered the actual transition zone between the distributions of A. franciscana and A. persimilis.

\section{Acknowledgements}

We thank the municipality of the city of General Acha for allowing entrance to the property where Utracán Lake is located and to the anonymous reviewers who, with their work, improved this article.

\section{Author Contributions}

Alicia María Vignatti: substantial contribution in the concept and design of the study; performing field and laboratory work; contribution to manuscript preparation and critical revision.

Gabriela Cecilia Cabrera: performing laboratory work; contribution to manuscript preparation and critical revision.

Santiago Andrés Echaniz: substantial contribution in the concept and design of the study; performing field and laboratory work; contribution to manuscript preparation and critical revision.

\section{Conflicts of interest}

The authors declares that they have no conflict of interest related to the publication of this manuscript. 


\section{References}

AMAT, F., COHEN, R.G., HONTORIA, F. \& NAVARRO, C. 2004. Further evidence and characterization of Artemia franciscana (Kellogg, 1906) populations in Argentina. J. Biogeogr. 31:1735-1749. DOI 10.1111/j.1365-2699.2004.01123.x.

APHA. 1992. Standard Methods for the Examination of Water and Wastewater. 18th edition. American Public Health Association (APHA), American Water Works Association (AWWA) and Water Pollution Control Federation (WPCF), Washington, DC.

ARAR, E.J. 1997. In Vitro Determination of Chlorophylls a, b, c + c and Pheopigments in Marine and Freshwater Algae by Visible Spectrophotometry. Method 446.0. U.S. Environmental Protection Agency.

BROWNE, R. \& WANIGASEKERA, G. 2000. Combined effects of salinity and temperature on survival and reproduction of five species of Artemia. J. Exp. Mar. Bio. Ecol. 244: 29-44.

CASAGRANDE, G., VERGARA, G. \& BELLINI, Y. 2006. Cartas agroclimáticas actuales de temperaturas, heladas y lluvia de la provincia de La Pampa (Argentina). Rev. Fac. Agronomía UNLPam 17 (1/2): 15-22.

CLEGG, J.S. \& GAJARDO, G. 2009. Two highly diverged New World Artemia species, A. franciscana and $A$. persimilis, from contrasting hypersaline habitats express a conserved stress protein complement. Comp. Biochem. Phys. A. 153:451-456. doi: 10.1016/j.cbpa.2009.04.613.

COHEN, R., RODRÍGUEZ GIL, S. \& VÉLEZ, C. 1999. The post-embryonic development of Artemia persimilis Piccinelli \& Prosdocimi. Hydrobiologia. 391(1-3): 63-80.

COHEN, R.G. 2012. Review of the biogeography of Artemia Leach, 1819 (Crustacea: Anostraca) in Argentina. Int. J. Artemia Biol. 2: 9-23.

D'AMBROSIO, D.S., CLAPS, M.C. \& GARCÍA, A. 2016. Zooplankton diversity of a protected and vulnerable wetland system in southern South America (Llancanelo area, Argentina). Int. Aquat. Res. 8:65-80. DOI 10.1007/s40071-016-0125-2.

DHONT, J. \& LAVENS, P. 1996. Tank production and use of ongrown Artemia. Pp. 164-195. In P. Lavens \& P. Sorgeloos (eds.). Manual on the Production and Use of Live Food for Aquaculture. FAO Fisheries Technical Paper 361, Rome.

DHONT, J. \& SORGELOOS, P. 2002. Applications of Artemia. In: Abatzopoulos T. J, Beardmore J. A, Clegg J. S, Sorgeloos P, eds, Artemia basic and applied biology. Kluwer Academic Publishers, Dordrecht: 251-277.

DI RIENZO, J.A., CASANOVES, F., BALZARINI, M.G., GONZÁLEZ, L.M., TABLADA, C. \& ROBLEDO, W. 2010. InfoStat (versión 2010). Grupo InfoStat, FCA, Universidad Nacional de Córdoba, Argentina.

ECHANIZ, S.A., CABRERA, G.C. \& VIGNATTI, A.M. 2015. Limnological parameters and population structure of Artemia persimilis Piccinelli and Prosdocimi, 1968 (Crustacea, Anostraca) in La Amarga, a hypersaline lake of La Pampa (Argentina). Res. Zool. 5(2): 25-31. (p-ISSN: 2325-002X; e-ISSN: 2325-0038). DOI: 10.5923/j.zoology.20150502.01.

GAJARDO, G.M., \& BEARDMORE, J. 2012. The brine shrimp Artemia: adapted to critical life conditions. Front. Phys. 3:1-8.

GREEN, A.J., SÁNCHEZ, M.I., AMAT, F., FIGUEROLA, J., HONTORIA, F., RUIZ, O. \& HORTAS, F. 2005. Dispersal of invasive and native brine shrimps Artemia (Anostraca) via waterbirds. Limnol. Oceanogr., 50(2): 737-742.

MECHALY, A.S., ANGELETTI, S., DE LOS RÍOS-ESCALANTE, P. \& CERVELLINI, P. M. 2013. A review of the biology and ecology of Artemia persimilis Piccinelli \& Prosdocimi, 1968 (Crustacea: Anostraca) as basis for its management. Int. J. Artemia Biol. 3(1): 12-19.
MECHALY, A.S., CERVELLINI, P.M. \& BAMBILL, G.A. 2004. Experiencias preliminares con Artemia persimilis (Crustacea, Anostraca) como potencial alimento vivo en acuicultura. AquaTIC. 21: 1-7.

MEDINA, G.R., GOENAGA, J., HONTORIA, F., COHEN, G. \& AMAT, F. 2007. Effects of temperature and salinity on prereproductive life span and reproductive traits of two species of Artemia (Branchiopoda, Anostraca) from Argentina: Artemia franciscana and A. persimilis. Hydrobiologia. 579: 41-53.

MUÑOZ, J., AMAT, F., GREEN, A., FIGUEROLA, J. \& GÓMEZ, A. 2013. Bird migratory flyways influence the phylogeography of the invasive brine shrimp Artemia franciscana in its native American range. PeerJ 1:e200; DOI 10.7717/ peerj.200.

PASTORINO, X.I., MARSCHOFF, E. \& COHEN, R.G. 2002. Reproductive and brood cycles of Artemia persimilis Piccinelli and Prosdocimi from Colorada Chica Lake (Province of La Pampa, República Argentina), under laboratory conditions. Hydrobiologia. 486: 279-288.

PÉREZ LÓPEZ, C. 2004. Técnicas de Análisis Multivariado de datos. Pearson Educación, Madrid. $676 \mathrm{p}$.

PILATI, A., CASTELLINO, M. \& BUCHER, E.H. 2016. Nutrient, chlorophyll and zooplankton seasonal variations on the southern coast of a subtropical saline lake (Mar Chiquita, Córdoba, Argentina). Ann. Limnol. - Int. J. Lim. 52: 263-271. DOI: 10.1051/limn/2016014

RUIZ, O., AMAT, F., SAAVEDRA, C., PAPESCHI, A., COHEN, R., BAXEVANIS, A., KAPPAS, I., ABATZOPOULOS, T. \& NAVARRO, J. 2008. Genetic characterization of Argentinean Artemia species with different fatty acid profiles. Hydrobiologia. 610: 223-234. DOI 10.1007/s10750-008-9437-6

SATO, N.E, MALLO, J.C. \& FENUCCI, J.L. 2004. Calidad de los quistes de Artemia persimilis (Piccinelli \& Prosdocimi) (Crustacea: Branchiopoda) de diferentes zonas de Argentina, como alimento en acuicultura. Rev. Biol. Mar. Oceanog. 39: 79-92.

SOKAL, R. \& ROHLF, F. 1995. Biometría. Principios y métodos estadísticos en la investigación biológica. Ed. Blume, Barcelona.

VERGARA, G. \& CASAGRANDE, G. 2012. Estadísticas agroclimáticas de la Facultad de Agronomía, Santa Rosa, La Pampa, Argentina. Rev. Fac. Agronomía UNLPam 22 (1): 3-74.

VIGNATTI, A.M., CABRERA, G.C., PILATI, A. \& ECHANIZ, S.A. 2014. Biology of Artemia persimilis Piccinelli and Prosdocimi, 1968 (Crustacea: Anostraca) at the highest salinities reported for the species under natural conditions. Int J. Artemia Biol. 4(1): 38-43.

VIKAS, P., SAGESHKUMAR, N., THOMAS, P., CHAKRABORTY, K. \& VIJAYAN, K. 2012. Aquaculture related invasion of the exotic Artemia franciscana and displacement of the autochthonous Artemia populations from the hypersaline habitats of India. Hydrobiologia. 684: 129-142.

WURTSBAUGH, W.A. \& GLIWICZ, Z.M. 2001. Limnological control of brine shrimp population dynamics and cyst production in the Great Salt Lake, Utah. Hydrobiologia. 466: 119-132.

ZAR, J.H. 1996. Biostatistical analysis. $3^{\circ}$ Ed. Prentice Hall, New Jersey.

Received: 19/04/2017

Revised: 01/09/2017

Accepted: 08/09/2017

Published online: 28/09/2017 